\title{
Distribution of phthalates in Marseille Bay (NW Mediterranean Sea)
}

\author{
Andrea Paluselli ${ }^{a}$, Vincent Fauvelle ${ }^{a}$, Natascha Schmidt ${ }^{a}$, François Galgani ${ }^{b}$, Sopheak Net ${ }^{c}$, Richard Sempéré ${ }^{\text {a,* }}$ \\ a Aix-Marseille Univ., Université de Toulon, CNRS, IRD, MIO, Marseille, France \\ b IFREMER, Laboratoire Environnement Ressources, Provence Azur Corse (LER/PAC), Ifremer Centre de Méditerranée, ZP de Bregaillon, La Seyne sur Mer, France \\ c Université de Lille, Laboratoire LASIR, Villeneuve d'Ascq, France
}

\section{H I G H L I G H T S}

- Estimation of DMP, DEP, DiBP, DnBP, BzBP and DEHP concentration at Bay of Marseille.

- One year PAEs observations (2014) in the Bay of Marseille.

- Variation of PAE composition from surface to the bottom water.

- High PAEs concentration close to deep and bottom water.

\section{G R A P H I C A L A B S T R A C T}

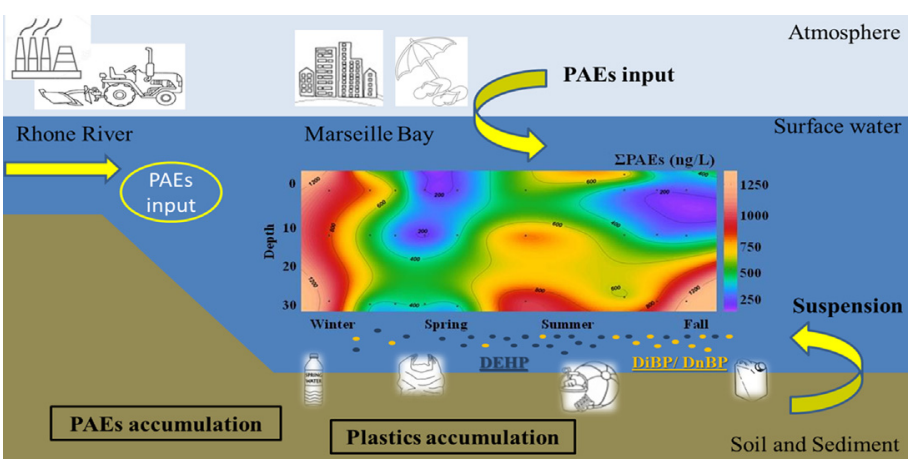

\section{A B S T R A C T}

Phthalic Acid Esters (PAEs) are a group of emerging organic contaminants that have become a serious issue because of their ubiquitous presence and hazardous impact on the marine environment worldwide. Seawater samples were collected monthly from December 2013 to November 2014 in the northwestern Mediterranean Sea (Marseille Bay). The samples were analyzed for dissolved organic carbon (DOC) as well as the molecular distribution of dissolved PAEs by using solid phase extraction followed by gas chromatography and mass spectrometry (GC/MS) analyses. The results demonstrated the occurrence of six PAEs, including dimethyl phthalate (DMP), diethyl phthalate (DEP), di-isobutyl phthalate (DiBP), di-n-butyl phthalate (DnBP), benzylbutyl phthalate (BzBP) and diethylhexyl phthalate (DEHP), with total concentrations ranging from 130 to $1330 \mathrm{ng} \mathrm{L}^{-1}$ (av. $522 \mathrm{ng} \mathrm{L}^{-1}$ ). In Marseille Bay, the highest concentrations were detected in the bottom water from June to November 2014 and in the whole water column during the winter mixing period. This result suggests that resuspension of PAErich sediment, in relation to the accumulation of plastic debris above the seabed, or the higher degradation rate in the upper layer of the water column, plays a significant role in the PAE dynamics in coastal water. DEHP was the most abundant PAE in all of the surface samples and the summer bottom samples, followed by DiBP and DnBP, which also represent the largest fractions in the other bottom samples.

(c) 2017 Elsevier B.V. All rights reserved.

\footnotetext{
* Corresponding author.

E-mail address: richard.sempere@mio.osupytheas.fr (R. Sempéré).
}

\section{Introduction}

Phthalates or phthalic acid esters (PAEs) are widely used in the manufacture and processing of plastic products such as plasticizers in a very broad range of industrial applications (Serôdio and Nogueria, 2006; Net 
et al., 2015a). PAEs account for approximately $92 \%$ of produced plasticizers and represent the most produced and consumed plasticizers worldwide (Rahman and Brazel, 2004; He et al., 2013) since these compounds are used to improve the flexibility of polyvinyl chloride (PVC) resins (Kimber and Dearman, 2010; Net et al., 2015b). Other industrial applications include the manufacturing of cosmetics, insect repellents, insecticide carriers and propellants (Net et al., 2015a; Net et al., 2015b; Xie et al., 2007). PAEs of lower molecular weight (LMW-PAEs: C3-C6) are used as essential components of solvents, adhesives, waxes, pharmaceutical products, insecticide materials and cosmetics, whereas PAEs of higher molecular weight (HMW-PAEs: C7-C13) are instead used as additives to improve the flexibility and handling of industrial materials (Holahan and Smith, 2015; IARC, 2000; Halden, 2010). These compounds are suspected to enter the environment directly as emissions from household and industrial products, as released by wastewater from production and processing activity or the use and disposal of materials (Staples et al., 1997) as well as from plastic polymer migration (Andrady, 2011).

Previous studies have shown that PAEs are endocrine-disrupting chemicals with the capability of inducing significant effects on the reproduction of various organisms, including protozoans, mollusks, crustaceans, fishes and invertebrates (Andrady, 2011), on the ecosystem functioning (Kolena et al., 2014) and on human obesity and cancer development (Okamoto et al., 2011; Howdeshell et al., 2008; Buckley et al., 2016; Wang et al., 2016). Therefore, PAEs have become a matter of concern for their potential risk to health and the environment. Six PAEs (dimethyl phthalate (DMP), diethyl phthalate (DEP), di-n-butyl phthalate (DnBP), benzylbutyl phthalate (BzBP), diethylhexyl phthalate (DEHP) and di-n-octyl phthalate (DnOP)) have been included as priority pollutants of the US-EPA (United States Environmental Protection Agency, 2014), the European Union (EU) (Commission Staff Working Document on the Implementation of the Community Strategy for Endocrine Disrupters-A Range of Substances Suspected of Interfering with the Hormone System of Humans and Wildlife, 2007) and the Chinese water list (National Standard of the People's Republic of China, 2006). Accordingly, monitoring PAEs in the major environmental matrices has become a priority. After their introduction in the environment, they can reach marine water by wastewater and riverine inputs, and end up in the sediment via association with humic acid and adsorption onto particles and finally end up in the sediment (Bauer et al., 1998). Due to the physiochemical properties and biogeochemical cycling of PAEs, they have been detected in food, air, water, soil and sediment (Net et al., 2015b; Turner and Rawling, 2000; Fromme et al., 2002; Horn et al., 2004; Brossa et al., 2005; Teil et al., 2007; Xie et al., 2005; Xie et al., 2006; Zeng et al., 2008; Ferreira and Morita, 2012; Fu et al., 2009; Fu et al., 2013). However, there is a lack of data related to their sources, distribution in the whole water column as well as their transfer mechanisms from the molecular state to different living species.

The Mediterranean Sea being a semi-enclosed basin with slow turnover time of $\sim 80$ years implies a sensitive response to anthropogenic impact (The Mermex Group, 2011). Mediterranean rivers and primarily the Rhone River supply large amounts of freshwater, particles and organic carbon to the Mediterranean Sea (Sempéré et al., 2000; Panagiotopoulos et al., 2012). There is extensive urbanization particularly along the coastline as well as a number of highly industrialized spots all along the Mediterranean basin that are concentrated mainly in the northwestern Mediterranean Sea. All these activities as well as agricultural and domestic activities (The Mermex Group, 2011; UNEP Chemicals, 2002) generate a large volume of wastewater, which provides marine litter, microplastics (Deudero and Alomar, 2015; Collignon et al., 2012; Cozar et al., 2015; Faure et al., 2015; Pedrotti et al., 2016; Suaria et al., 2016; Ruiz-Orejon et al., 2016; Schmidt et al., submitted), anthropogenic molecules (Sicre et al., 2008; Sempéré et al., in press), persistent organic pollutants (POPs) and related contaminants such as polycyclic aromatic hydrocarbons (PAHs) and polychlorinated dibenzo-p-dioxins and dibenzofurans (PCDD/Fs) (The
Mermex Group, 2011; Berrojalbiz et al., 2011; Castro-Jimenez et al., 2010) that impact the coastal marine ecosystems in unknown proportion. However, only a few studies have reported the occurrence of individual phthalates in the Mediterranean Sea (Brossa et al., 2005; Sanchez-Avila et al., 2012), and there is only one study dealing with the distribution of a series of PAEs in the Mediterranean basin (Paluselli et al., in press). The objectives of the present study are to investigate the composition and distribution of PAEs in the NW Mediterranean coastal seawater column and to ascertain their temporal trends on an annual basis.

\section{Materials and methods}

\subsection{Study area, sampling, and dissolved organic carbon analyses}

Seawater samples $(n=72)$ were collected with R/V Antedon from the SUNMEX station (Fig. 1) in the northwestern Mediterranean Sea in Marseille Bay $\left(43^{\circ} 18^{\prime} \mathrm{N}, 05^{\circ} 22^{\prime} \mathrm{E}\right)$ from December 2013 to November 2014 at $1.5,5,15$ and $30 \mathrm{~m}$ (with a bottom depth of 32-33 m) with a 12L GO-FLOC (GENERAL OCEANICS) bottle previously rinsed with $1 \%$ hydrochloric acid and ultrapure water to avoid contamination. Immediately after sampling, the seawater samples were directly transferred from the GO-FLOC into 5 -L precombusted $\left(450^{\circ} \mathrm{C}\right.$ for $6 \mathrm{~h}$ ) glass bottles closed with PTFE (polytetrafluoroethylene) lined screw caps, wrapped with aluminum foil and brought back to the laboratory within $4 \mathrm{~h}$ for processing. Four samples collected in October 2014 at Marseille Bay were already published (Paluselli et al., in press). The samples were filtrated through precombusted $\left(450^{\circ} \mathrm{C}\right.$ for $6 \mathrm{~h}$ ) GFF filters (47-mm filter diameter, rinsed with $2 \mathrm{~L}$ of Milli-Q water and $150 \mathrm{~mL}$ of sample prior to filtration) in a glass apparatus directly and transferred into 1-L glass bottles. After filtration, duplicate subsamples $(10 \mathrm{~mL})$ were collected for dissolved organic carbon (DOC) analyses with precombusted Pasteur pipettes, transferred into precombusted glass vials, poisoned with sulfuric acid to $\mathrm{pH} \sim 2$ to avoid any biological activity, closed with PTFE-lined screw caps and stored in the dark at $4{ }^{\circ} \mathrm{C}$. DOC concentrations were measured using a Shimadzu TOC-5000 carbon analyzer (Sempéré et al., 2008). The nominal analytical precision of the procedure was within $2 \%$. The accuracy of the instrument and the system blank were determined by analyzing reference materials (D. Hansell, Rosenstiel School of Marine and Atmospheric Science, Miami, USA), including the Deep Seawater reference (DSR) and low carbon water (LCW) reference materials. The average DOC concentrations in the DSR and LCW reference standards were $45 \pm 2 \mu \mathrm{M} \mathrm{C}, n=24$ and $1 \pm$ $0.3 \mu \mathrm{M} \mathrm{C}, n=24$, respectively.

All glassware including Pasteur pipettes, glass bottles and glass filtration apparatus was previously cleaned in $1 \%$ hydrochloric acid bath, rinsed with ultrapure water and combusted at $450{ }^{\circ} \mathrm{C}$ for $6 \mathrm{~h}$. All the GC/MS and DOC seawater analyses were conducted in duplicate in the MIO laboratory in Marseille within 6 months. Filtration of samples was conducted in the MIO ISO class 6 chemistry cleanroom (temperature: $22{ }^{\circ} \mathrm{C}$; SAS pressure: $+15 \mathrm{~Pa}$; SAS brewing rate: $30 \mathrm{vol} / \mathrm{h}$; lab pressure: + $30 \mathrm{~Pa}$; brewing rate: $50 \mathrm{vol} / \mathrm{h})$.

\subsection{Phthalates analyses}

Seven phthalates were studied including dimethyl phthalate (DMP), diethyl phthalate (DEP), di-isobutyl phthalate (DiBP), di-n-butyl phthalate (DnBP), benzylbutyl phthalate (BzBP), diethylhexyl phthalate (DEHP) and di-n-octyl phthalate (DnOP) (Fig. 2). The deuterated internal standards were: DEP-d4, DnBP-d4, DEHP-d4. All native and labeled standards were of high purity grade ( $>98 \%, 2000 \mu \mathrm{g} \mathrm{mL}^{-1}$ Supelco). Stock solutions were prepared in hexane and stored in the dark at $4{ }^{\circ} \mathrm{C}$. Working solutions (unlabeled and labeled standards) were prepared by dilution of these solutions at $20 \mathrm{mg} \mathrm{L}^{-1}$. All solvents were glass-distilled grade and supplied by Rathburn Chemicals Ltd. (Walkerburn, UK). Milli-Q water was produced on-site on a Milli-Q 


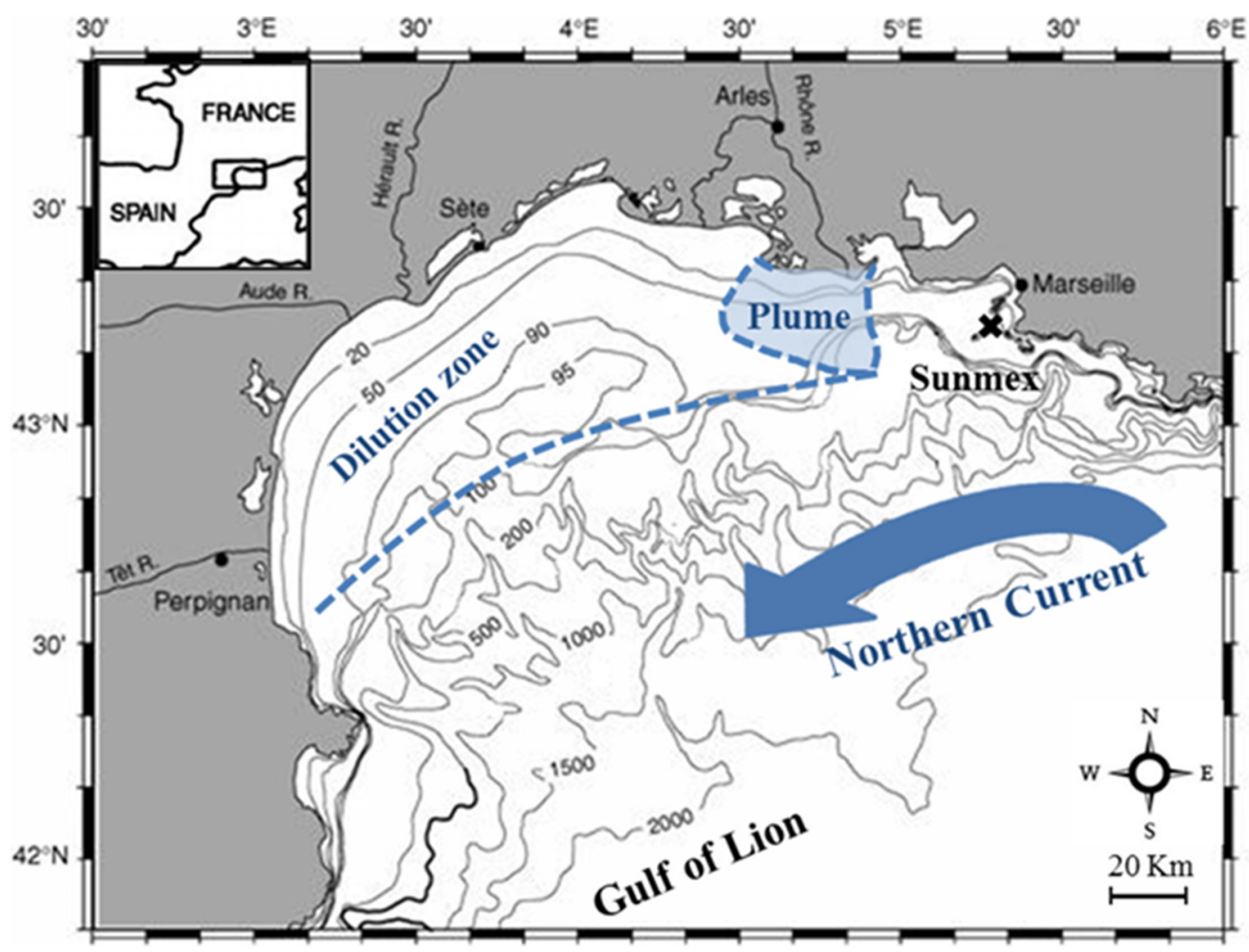

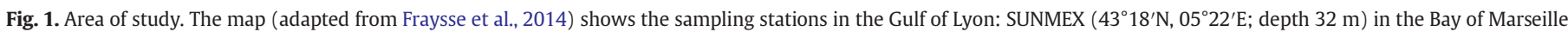

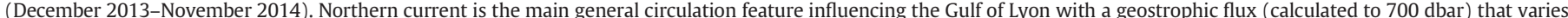

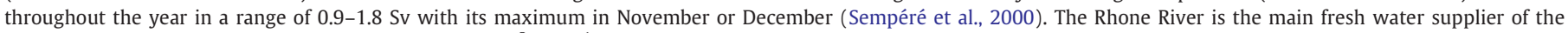

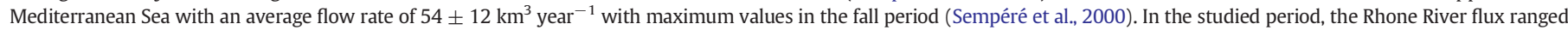
from 1300 to $2800 \mathrm{~m} 3 \mathrm{~s}^{-1}$.

system, Millipore (Molsheim, France) with resistivity higher than $18.2 \mathrm{M} \Omega \mathrm{cm}\left(25^{\circ} \mathrm{C}\right)$ and Total Organic Carbon $<2 \mu \mathrm{g} \mathrm{L}{ }^{-1}$.

The extractions were performed following the method optimized for seawater PAE detection at trace levels (Paluselli et al., in press). PAEs were extracted by solid phase extraction (SPE) from seawater using a precombusted 6-mL glass reaction tube containing $200 \mathrm{mg}$ of Oasis $\AA$ HLB sorbent (Waters Corporation, $30 \mu \mathrm{m}, 100 \mathrm{~g}$ ). SPE was conducted on a Visiprep vacuum manifold from Sigma-Aldrich (Saint Quentin Fallavier, France). Before sample extraction, SPE cartridges were three times sequentially cleaned with $5 \mathrm{~mL}$ of acetone, $5 \mathrm{~mL}$ of dichloromethane, conditioned with $5 \mathrm{~mL}$ of ethyl acetate, $5 \mathrm{~mL}$ of acetone and $5 \mathrm{~mL}$ of ultrapure water prior sample processing. Seawater samples were spiked (for recovery estimate) with DEP-d4, DnBP-d4 and DEHP-d4 at 50, 200 and $400 \mathrm{ng} \mathrm{L}^{-1}$, respectively, prior to loading onto SPE cartridges under<smiles>COC(=O)c1ccccc1C(=O)OC</smiles>

Dimethyl phthalate (DMP)<smiles>CC(C)COC(=O)c1ccccc1C(=O)OCC(C)C</smiles>

\section{Diisobutyl phthalate (DiBP)}<smiles>CCOC(=O)c1ccccc1C(=O)OCC</smiles>

Diethyl phthalate (DEP)<smiles>CCCCOC(=O)c1ccccc1C(=O)OCc1ccccc1</smiles>

Benzylbutyl phthalate (BzBP)<smiles>CCCCOC(=O)c1ccccc1C(=O)OCCCC</smiles>

Dibutyl phthalate (DnBP)<smiles>CCCCC(CC)COC(=O)c1ccccc1C(=O)OCC(CC)CCCC</smiles>

Diethylhexyl phthalate (DEHP)

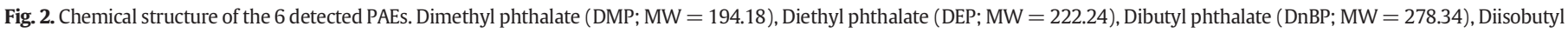
phthalate (DiBP; MW = 278.34), Benzylbutyl phthalate (BzBP; MW = 312.36) and Diethylhexyl phthalate $(\mathrm{DEHP} ; \mathrm{MW}=390.56)$.

Figure adapted from Xie et al., 2007. 
vacuum at a flow rate of 5 to $10 \mathrm{~mL} \mathrm{~min}^{-1}$. Then, $5 \mathrm{~mL}$ of ultrapure water was percolated to remove the remaining salt and air-dried for around $1 \mathrm{~h}$ under vacuum. PAEs were eluted into precombusted $10 \mathrm{~mL}$-vials by a 2-step percolation of $3 \mathrm{~mL}$ of ethyl acetate. Ethyl acetate was gently evaporated to a final volume of $200 \mu \mathrm{L}$ at room temperature under a gentle stream of nitrogen (purity $>99,995 \%$ ). Then, samples were immediately closed with PTFE lined screw caps rubbed with PTFE ribbon and stored before injection in the dark at $-20{ }^{\circ} \mathrm{C}$.

Analysis was performed using an Agilent Technologies 6850 GC system coupled to an Agilent Technologies 5975C mass spectrometer (GC) MS) operated with electron impact ionization $(70 \mathrm{eV})$. Chromatographic separation was achieved on an Agilent HP-5MS capillary column (30 $\mathrm{m} \times 0.25 \mathrm{~mm}, 0.25 \mu \mathrm{m}$ film thickness) with the GC oven programmed at $70{ }^{\circ} \mathrm{C}$ for $1 \mathrm{~min}$ and then up to $230^{\circ} \mathrm{C}$ at $30{ }^{\circ} \mathrm{C} \mathrm{min}-1$, to $250{ }^{\circ} \mathrm{C}$ at $8{ }^{\circ} \mathrm{C} \mathrm{min}-1$ and to $280^{\circ} \mathrm{C}$ at $30^{\circ} \mathrm{C} \mathrm{min}^{-1}$ with a final isotherm hold for $7.50 \mathrm{~min}$. Helium was used as a carrier gas at a flow rate of $1.1 \mathrm{~mL} \mathrm{~min}^{-1}$. Samples were manually injected $(2 \mu \mathrm{L})$ on a splitless mode injector with a temperature set at $250{ }^{\circ} \mathrm{C}$. The injector (Merlin Microseal system) was used as a low carryover septum and a gas purifier (Charcoal, CP17972) to prevent contamination during the injection. Data were acquired in single ion monitoring (SIM) mode for increased sensitivity with a dwell time of $100 \mathrm{~ms}$. Data were collected and analyzed with the Agilent ChemStation software.

\subsection{Quality control and quality assurance}

For each batch of 12 samples, a method blank, a spiked blank and a sample duplicate were processed. The retention time and the response factors of GC/MS were assessed for each analytical sequence from daily control standards to ensure the most appropriate quantification. The average recoveries of PAEs spiked in seawater samples showed acceptable recovery for all phthalates, ranging from $97 \% \pm 3 \%$ for DEP to $110 \% \pm 7 \%$ for DiBP. Internal standard recoveries were estimates as $94 \% \pm 2 \%$ for DEP-d $4,77 \% \pm 3 \%$ for DnBP-d4 and $14 \% \pm 2 \%$ for DEHPd4. All material was produced in borosilicate glass previously kept in an acidic bath overnight ( $10 \%$ hydrochloric acid), rinsed with ultrapure water, combusted at $450{ }^{\circ} \mathrm{C}$ for $6 \mathrm{~h}$ and rinsed with methanol and dichloromethane before use. Extractions were carried out in controlled air conditions in an ISO class 6 chemistry cleanroom (temperature: 22 ${ }^{\circ} \mathrm{C}$; SAS pressure: $+15 \mathrm{~Pa}$; SAS brewing rate: $30 \mathrm{vol} / \mathrm{h}$; lab pressure: $+30 \mathrm{~Pa}$; brewing rate: $50 \mathrm{vol} / \mathrm{h}$ ). Although precautions were considered to prevent sample contamination during the protocol, DEP, DiBP and occasionally DnBP were detected in the blanks at levels that remained below $0.07 \pm 0.02 \mathrm{ng} \mathrm{L}^{-1}, 0.8 \pm 0.3 \mathrm{ng} \mathrm{L}^{-1}$ and $0.7 \pm 0.2 \mathrm{ng} \mathrm{L}^{-1}$, respectively. DEHP was occasionally detected in blanks between the method detection limit (MDL) and the quantification detection limit (QDL). Limits of detection (LOD) were derived from the blanks and quantified as mean blanks plus three times the standard deviation of blanks, and they ranged from $0.11 \mathrm{ng} \mathrm{L}^{-1}$ for DMP to $1.67 \mathrm{ng} \mathrm{L}^{-1}$ for DEHP.

\subsection{Statistics}

Principal component analysis (PCA) was applied to reduce the multidimensional nature of the dataset and to evaluate the interrelationships among the PAEs, sites and sampling periods. PCA was performed using the individual phthalate concentrations (i.e. DEHP, DiBP) as PCA parameters. This data set was transformed in two smaller matrices that are linear combinations of the original data set. The number of observations in this study is 216 , which permits the use of this statistical approach. The PCA statistics were performed using the statistical package XLSTAT 2010.2 (Addinsoft). Time series maps were made using the latest Ocean Data View version: ODV 4.7.4.

\section{Results and discussion}

\subsection{General characteristics of the water column}

The hydrological data (Fig. 3) are in line with previous well-known features in Marseille Bay and the local coastal area indicating that (Serôdio and Nogueria, 2006) the water column was well mixed during winter and fall periods, most of the time under the action of wind (Fraysse et al., 2014; Gatti et al., 2006; Barrier et al., 2016), whereas (Net et al., 2015a) the water began warming in May $\left(16-17^{\circ} \mathrm{C}\right)$ causing water stratification. It is noteworthy that lower salinity was observed in October-November 2014 probably in association with freshwater intrusion (Fig. 3b). The DOC distribution (Fig. 3e) showed a clear seasonal trend with a concentration range of $62.5-72.5 \mu \mathrm{M}$ in winter-spring and 72.5-90 $\mu \mathrm{M}$ during summer-fall. Higher DOC values (79-81 $\mu \mathrm{M})$ were observed in the spring water column as well as above the bottom in winter. As a byproduct of primary production, the DOC distribution highlighted higher concentrations in spring-summer following phytoplankton growth (Fig. 3d). The high DOC concentrations near the bottom and in the whole water column during winter might instead be explained by resuspension of rich organic sediment and subsequent mixing under the action of wind as previously reported from CDOM (colored dissolved organic matter) and DOC time series studies (Para et al., 2010; Sempéré et al., 2015). Such low DOC concentrations were comparable to those previously reported in open waters of the Mediterranean Sea (Doval et al., 1999; Dafner et al., 2001; Santinelli et al., 2012; Sempéré et al., 2002; Sempéré et al., 2003), with a stable annual mean of $67 \pm 7 \mu \mathrm{MC}$ at $2 \mathrm{~m}$ and $63 \pm 6 \mu \mathrm{MC}$ at $5 \mathrm{~m}$.

\subsection{Concentration and relative abundance of PAEs in Marseille Bay}

All targeted PAEs were detected in all samples collected at SUNMEX station except DnOP. During the studied period, the sum of the 6 PAEs' concentrations in the water column ( $\mathrm{PAEs}$ ) ranged from 130 to $1330 \mathrm{ng} \mathrm{L}^{-1}$ (av. $520 \mathrm{ng} \mathrm{L}^{-1}$; Table 1; Fig. 3f) in Marseille Bay. The highest $\Sigma$ PAEs concentrations were observed all along the well mixed water column in winter 2013 as well as near the bottom in the May-August and September-December 2014 periods (Fig. 3). By contrast, the lowest $\Sigma$ PAEs concentrations were found in shallower waters between 0.5 and $15 \mathrm{~m}$ by the end of winter and in October-November 2014 where low salinities were observed (Fig. 3b). Note that the October-November 2014 period corresponds to possible freshwater intrusion into Marseille Bay (Gatti et al., 2006) as suggested by lower salinity values (Fig. 3b). In Marseille Bay, for 62 out of 72 samples, DEHP (9.3-91.6\%) was the most abundant PAE, followed by DiBP (3.8-78\%) and DnBP (2.1-44.8\%) (Figs. 4-5; Table 1). By contrast, DMP, DEP and BzBP were the least abundant $(0.2-2 \%)$ and can be considered minor species here.

Very limited data are available for the occurrence and fate of PAEs as a simultaneous series in marine waters and more specifically in both the Mediterranean Sea and river waters, making any comparison of $\Sigma$ PAEs data with existing studies difficult. However we found that our data are consistent with literature. Indeed, examination of already published individual PAEs, indicated that our DEHP concentrations (20-920 ng L ${ }^{-1}$; Table 1) were in the same range as values reported for NW Spanish coastal seawater (30-620 ng L ${ }^{-1}$; (Sanchez-Avila et al., 2012)) and the southern coast of the UK (100-2200 ng L ${ }^{-1}$; (Turner and Rawling, 2000)) but one order of magnitude lower than that for the Northern Mediterranean Spanish coast (Brossa et al., 2005). Noteworthy lower values were also reported in the North Sea for DEHP $\left(0.5-5.3 \mathrm{ng} \mathrm{L}^{-1}\right)$, DMP as well as DEP (0.02-4.0 ng L ${ }^{-1}$ ) (Teil et al., 2007; Dargnat et al., 2009). Similar concentrations of DEHP, $161-314$ and 323-779 $\mathrm{ng} \mathrm{L}^{-1}$, were found in the Seine River whereas DMP concentrations were reported in the range of 2.5-5.5 $\mathrm{ng} \mathrm{L}^{-1}$ in six Spanish rivers including Ebro River (Sanchez-Avila et al., 2012). DEP was detected in different studies in the Seine River (France) in a range slightly higher than our data, from 46 to $208 \mathrm{ng} \mathrm{L}^{-1}$ (Teil et al., 2007) to $71-181 \mathrm{ng} \mathrm{L}^{-1}$. (Dargnat et 


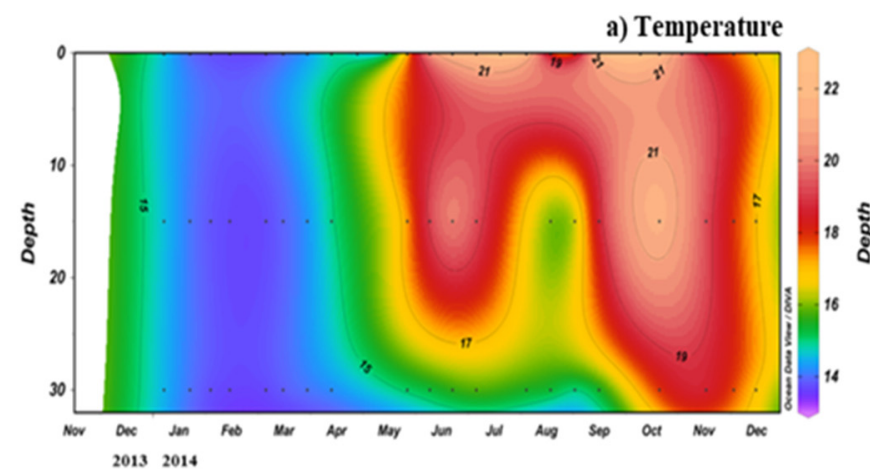

c) Oxygen

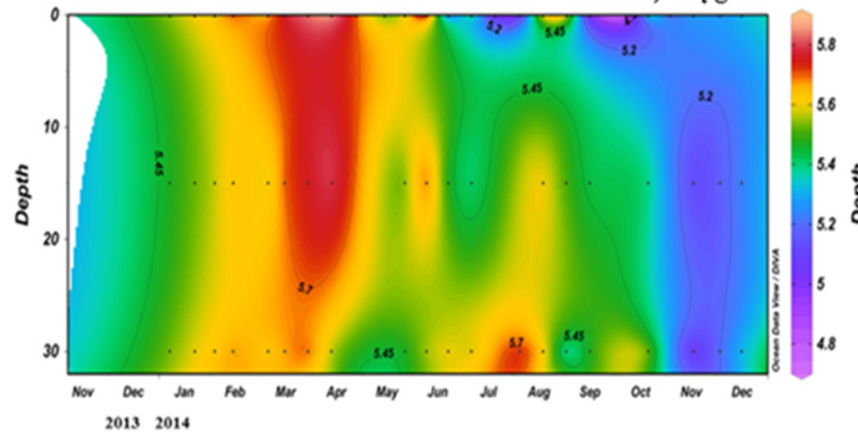

e) $\mathrm{DOC}$

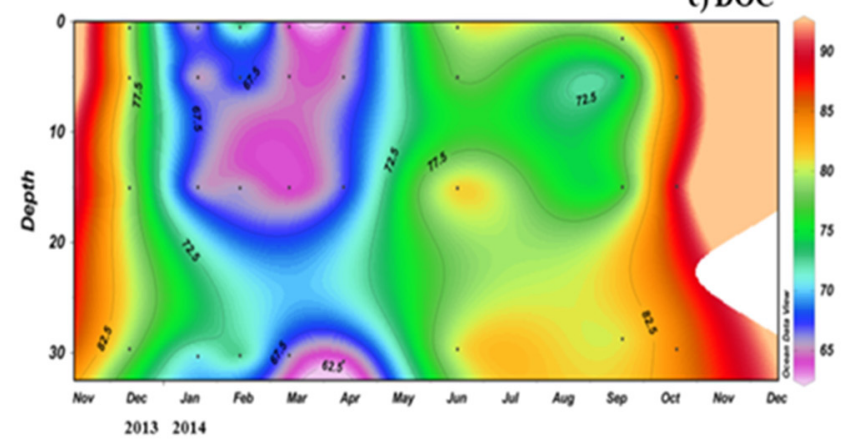

b) Salinity

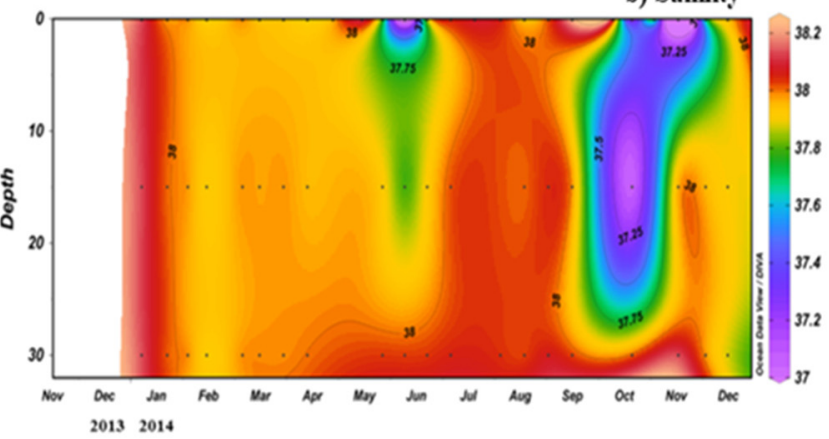

d) $\mathrm{Chl} \mathrm{A}$

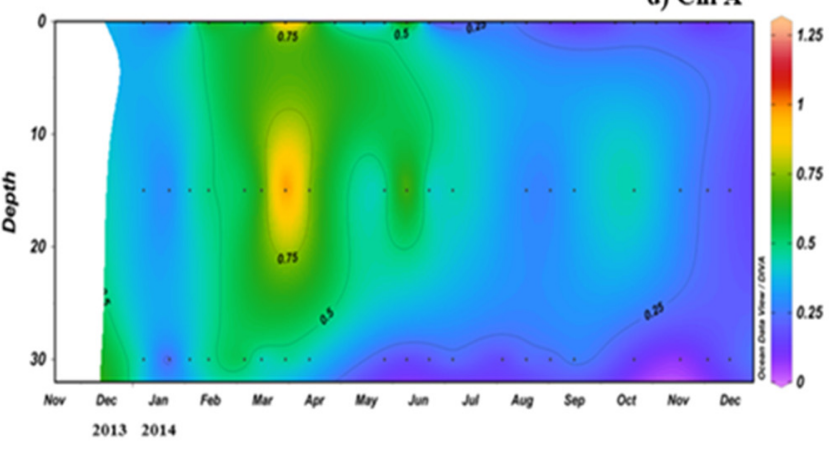
20132014

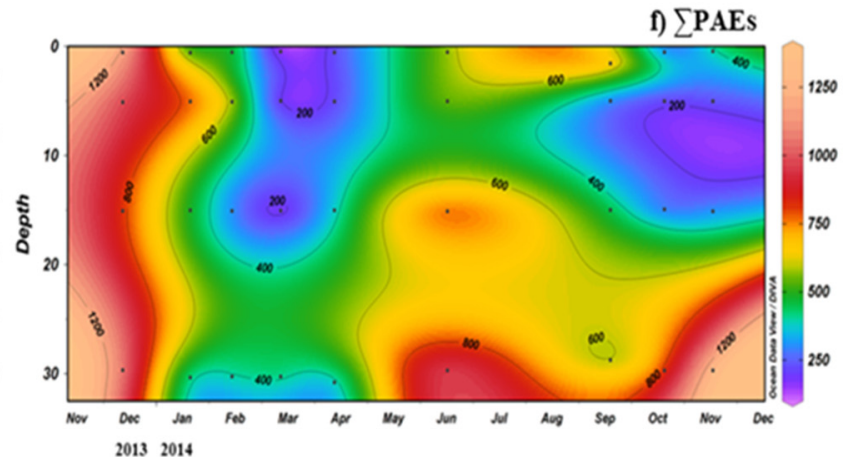

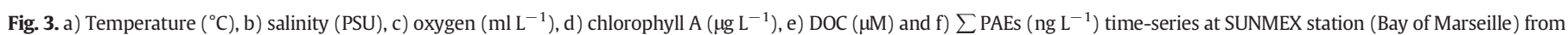
December 2013 to November 2014. Samples were collected at 1.5, 5, 15 and $30 \mathrm{~m}$.

al., 2009) as well as 52-284 ng L ${ }^{-1}$ in 6 Spanish rivers (Sanchez-Avila et al., 2012). BzBP was also reported at low concentration in the range of 4.8-23 ng L ${ }^{-1}$ (Sanchez-Avila et al., 2012; Dargnat et al., 2009). Limited data are available for the distribution of PAEs in coastal seawater.

The contribution of carbon from PAEs to the DOC pool (PAE-C) accounted for 10-60 ppm. A comparison with other organic compounds within the DOC pool identified in the coastal Mediterranean Sea indicated that our PAE concentrations are in the same order of magnitude as the reported values of dissolved water phase PAHs (3-120 $\mathrm{ng} \mathrm{L}^{-1}$; (Berrojalbiz et al., 2011)), one of the most abundant classes of organic contaminants in the marine environment. Lower concentration range was reported for other organic pollutant as PFCs (0.07-4.55 $\mathrm{ng} \mathrm{L}^{-1}$; (Sanchez-Avila et al., 2012; Ahrens et al., 2010)) in NW Mediterranean Sea, PCB (2.2-82.4 pg L ${ }^{-1}$; (Berrojalbiz et al., 2011)) in surface water of Mediterranean Sea and PBDE, another group of compounds used as additives in polymer, detected in Aegean Sea with concentration range of 4-6 pg L ${ }^{-1}$ (Lammel et al., 2015). PCDD/Fs was reported with two orders of magnitude lower than PAEs concentration (42.5-64.0 $\mathrm{fg} \mathrm{L}^{-1}$ ) (Castro-Jimenez et al., 2008). However, PAE concentrations are nevertheless two orders of magnitude lower than the sum of $\alpha, \omega$-dicarboxylic acids $\left(20.7 \pm 10.6 \mu \mathrm{g} \mathrm{L}^{-1}\right)$ and $\omega$-oxoacids $\left(11.7 \pm 6.2 \mu \mathrm{g} \mathrm{L}^{-1}\right)$ in the Marseille coastal area (Tedetti et al., 2006) or in the Rhone River close to the Marseille Bay (Sempéré et al., in press).

\subsection{PCA analysis}

The grouping of samples by depth and season using principal component analysis (PCA) formed several clusters (samples scores, Fig. 6a) over PC1 and PC2 that represent $79.7 \%$ of the total information. Samples collected at Marseille Bay formed five well-identified clusters (Fig. 6a) including the fall samples in the lower left quadrant, the spring in the central left, the summer in the upper left, winter samples in the upper right quadrant and the bottom samples in the right quadrant. Of the biomarkers plotted, DMP, DEP and DnBP being positive on PC1 and most negative on PC2 form a compact cluster on the central-right quadrant and separated from DEHP located in the upper quadrant (positive on PC1 and PC2 factors) and from DiBP in the lower quadrant (positive on PC1 and negative on PC2). DEHP is a plasticizer used in the manufacture of PVC and other plastic products. On the other hand, the presence of LMW-PAEs in the same group is related to their common use as components of solvents, adhesives, pharmaceutical products, insecticide materials and cosmetics.

In brief, the PCA score plot therefore highlights that i) summer and winter groups have a similar pattern i.e. highest concentrations of DEHP, DMP and DEP, together with lowest concentrations of DiBP; ii) fall and spring groups are also very close on Fig. 6a: their intensity on both PC1 and PC2 axis are low and negative, meaning low $\Sigma$ PAEs 
Table 1

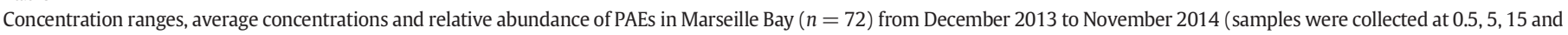
$30 \mathrm{~m}$ depth).

\begin{tabular}{|c|c|c|c|c|c|}
\hline & \multirow[t]{3}{*}{ Depth (m) } & \multicolumn{2}{|c|}{ Concentrations ( $\left.\mathrm{ng} \mathrm{L}^{-1}\right)$} & \multicolumn{2}{|c|}{ Relative abundance (\%) } \\
\hline & & Range & Av. \pm SD & \multirow[t]{2}{*}{ Range } & \multirow{2}{*}{ Av. \pm SD } \\
\hline & & \multicolumn{2}{|c|}{ Bay of Marseilles (Dec 2013-Nov 2014) } & & \\
\hline \multirow[t]{5}{*}{ Dimethyl phthalate (DMP) } & 0.5 & $0.9-6.9$ & $2.8 \pm 2.2$ & $0.2-1.4$ & $0.6 \pm 0.3$ \\
\hline & 5 & $0.8-6.8$ & $2.9 \pm 2.0$ & $0.3-1.1$ & $0.7 \pm 0.4$ \\
\hline & 15 & $0.8-7.7$ & $2.7 \pm 2.3$ & $0.2-0.9$ & $0.6 \pm 0.3$ \\
\hline & 30 & $2.1-11.9$ & $4.5 \pm 2.1$ & $0.2-1.2$ & $0.7 \pm 0.3$ \\
\hline & Total & $0.8-11.9$ & $3.2 \pm 2.4$ & $0.2-1.4$ & $0.6 \pm 0.3$ \\
\hline \multirow[t]{5}{*}{ Diethyl phthalate (DEP) } & 0.5 & $3.4-25.7$ & $11.8 \pm 7.6$ & $1.1-4.9$ & $2.6 \pm 1.4$ \\
\hline & 5 & $6.3-27.2$ & $11.9 \pm 7.9$ & $1.1-10.2$ & $3.4 \pm 2.7$ \\
\hline & 15 & $3.3-45.5$ & $13.9 \pm 13.4$ & $0.9-9.9$ & $3.3 \pm 2.7$ \\
\hline & 30 & $8.9-50.0$ & $25.3 \pm 12.6$ & $0.9-5.1$ & $3.8 \pm 1.3$ \\
\hline & Total & $3.3-50.0$ & $15.7 \pm 12.5$ & $0.9-10.2$ & $3.3 \pm 2.1$ \\
\hline \multirow[t]{5}{*}{ Diisobutyl phthalate (DiBP) } & 0.5 & $34.2-215.7$ & $89.5 \pm 70.3$ & $4.3-68.0$ & $24.3 \pm 21.9$ \\
\hline & 5 & $30.1-155.3$ & $62.0 \pm 37.9$ & $3.8-78.0$ & $23.3 \pm 23.1$ \\
\hline & 15 & $29.4-155.1$ & $71.1 \pm 39.6$ & $4.7-64.2$ & $20.2 \pm 18.6$ \\
\hline & 30 & $50.8-383.4$ & $188.5 \pm 124.8$ & $5.0-42.5$ & $28.0 \pm 11.5$ \\
\hline & Total & $27.5-383.4$ & $102.7 \pm 90.5$ & $3.8-78.0$ & $23.9 \pm 18.7$ \\
\hline \multirow[t]{5}{*}{ Dibutyl phthalate (DnBP) } & 0.5 & $12.0-314.6$ & $76.7 \pm 66.7$ & $2.6-26.3$ & $11.1 \pm 7.9$ \\
\hline & 5 & $14.0-196.5$ & $58.3 \pm 50.9$ & $2.7-26.1$ & $11.1 \pm 7.3$ \\
\hline & 15 & $12.0-178.6$ & $61.4 \pm 48.9$ & $2.8-42.1$ & $14.2 \pm 12.0$ \\
\hline & 30 & $21.0-596.0$ & $173.8 \pm 165.0$ & $2.1-44.8$ & $19.4 \pm 13.7$ \\
\hline & Total & $12.0-596.0$ & $83.2 \pm 75.2$ & $2.1-44.8$ & $13.9 \pm 10.7$ \\
\hline \multirow[t]{5}{*}{ Benzylbutyl phthalates (BzBP) } & 0.5 & $2.7-4.9$ & $3.7 \pm 0.7$ & $0.4-2.0$ & $1.0 \pm 0.6$ \\
\hline & 5 & $2.6-4.6$ & $3.6 \pm 0.6$ & $0.5-1.8$ & $1.1 \pm 0.5$ \\
\hline & 15 & $2.6-4.6$ & $3.6 \pm 0.6$ & $0.5-1.8$ & $1.0 \pm 0.4$ \\
\hline & 30 & $3.6-6.1$ & $4.4 \pm 0.9$ & $0.4-1.5$ & $0.8 \pm 0.4$ \\
\hline & Total & $2.6-6.1$ & $3.8 \pm 0.7$ & $0.4-2.0$ & $0.9 \pm 0.5$ \\
\hline \multirow[t]{5}{*}{ Diethylhexyl phthalate (DEHP) } & 0.5 & $42.3-802.0$ & $331.4 \pm 257.1$ & $18.5-89.3$ & $61.0 \pm 23.8$ \\
\hline & 5 & $15.8-714.0$ & $317.0 \pm 274.1$ & $9.3-90.2$ & $61.1 \pm 24.7$ \\
\hline & 15 & $51.3-525.0$ & $291.9 \pm 221.5$ & $21.2-91.1$ & $61.4 \pm 24.1$ \\
\hline & 30 & $130.0-923.8$ & $328.6 \pm 257.9$ & $18.3-91.6$ & $48.1 \pm 23.9$ \\
\hline & Total & $15.8-923.8$ & $317.2 \pm 242.7$ & $9.3-91.6$ & $57.9 \pm 23.8$ \\
\hline Total PAEs & & $130.8-1330.7$ & $522.7 \pm 313.3$ & 100 & \\
\hline
\end{tabular}

concentration rather than a specific PAE mix; and iii) bottom samples are mainly driven by DiBP concentration, and are thus clearly separated from upper water layers whatever the season.

\subsection{Potential sources and sinks of PAEs in the water column}

The averaged concentrations of PAEs found in Marseille Bay (522.7 $\pm 313.3 \mathrm{ng} \mathrm{L}^{-1}$ ) samples are significantly higher than that previously found offshore (maximum depth $2500 \mathrm{~m})\left(135 \pm 74 \mathrm{ng} \mathrm{L}^{-1}\right.$. (Paluselli et al., in press)) suggesting that the freshwater input and urban area provide a significant amount of PAEs to Marseille Bay. Our results also indicated i) significant seasonal variations of $\Sigma$ PAEs in Marseille Bay suggesting variability in sources, degradation processes of PAEs occurring in coastal seawaters, and/or partitioning of PAEs onto particulate matter; ii) heterogeneous vertical distribution by the end of winter/spring and homogenous concentration in the whole water column in the winter period with a large $\Sigma$ PAEs increase of concentration above the sea floor at different periods of the year.

\subsubsection{Seasonal variation}

Concerning seasonal variation in Marseille Bay, it is interesting to note that elevated concentration of PAEs (Fig. 3f) in summer coastal seawater nearby the Marseille urban area is concomitant with (Serôdio and Nogueria, 2006) the intense recreational coastal activities that reach their maximum during the summer on the beaches of Marseille, as well as (Net et al., 2015a) the elevated maritime traffic occurring during the tourist season between the ports of the coastal study area. As DEHP is predominant during the summer period (Figs. 4-5), it is likely that such summer activities preferentially generate inputs of DEHP-rich PAE into coastal seawater. It should be noticed that DEHP is the most abundant plasticizer for PVC, PVA and rubber materials that are widely used at sea through surfing, diving and swimming or left on the beaches such as food packaging, bags and sunscreen containers. The high turnover of cruise ships could also represent a significant source of DEHP for the coastal area. In Marseille Bay, the large variations of PAE concentrations in the first $25 \mathrm{~m}$ of the water column could be connected to variation of input and degradation processes as well. Few PAE-degrading bacteria have been isolated from marine environments ( $\mathrm{Gu}$ et al., 2009) and a recent study suggests that the ability to degrade phthalate and its monoesters is widespread in Japanese seawater from bacteria related to 11 different genera (Iwaki et al., 2012). It is likely that prokaryotic degradation processes regulate the PAE concentration in the water column as well.

\subsubsection{Higher concentration near the bottom}

Interestingly, we found that PAE concentrations are quite elevated above the bottom being, in most cases, higher than the corresponding concentration on the sea surface (Figs. 3f-7), with the exclusion of winter 2013 and September for which PAE concentrations are similar in the whole water column probably because of winter mixing under the action of Mistral wind (Fraysse et al., 2014). Such an accumulation of PAEs near the bottom has already been reported in a previous study in offshore Mediterranean seawater at $2000 \mathrm{~m}$ depth (Paluselli et al., in press). A gradient in the PAE concentration might be either due to i) preferential photochemical and/or prokaryotic degradation in the surface water column rather than in deeper seawater, giving rise to accumulation of PAEs above the seafloor, or ii) PAE input directly from the bottom by pure chemical diffusion and/or advection phenomena (resuspension of sediment or bioturbation).

Surface water column photochemical degradation is certainly more effective in the first meters of the water column whereas prokaryotic degradation is likely to be more efficient above the sediment. Although PAE-degrading bacteria have been isolated from marine environments (Gu et al., 2009; Iwaki et al., 2012), preferential biodegradation in the 
a) $\operatorname{DEHP}(\%)$

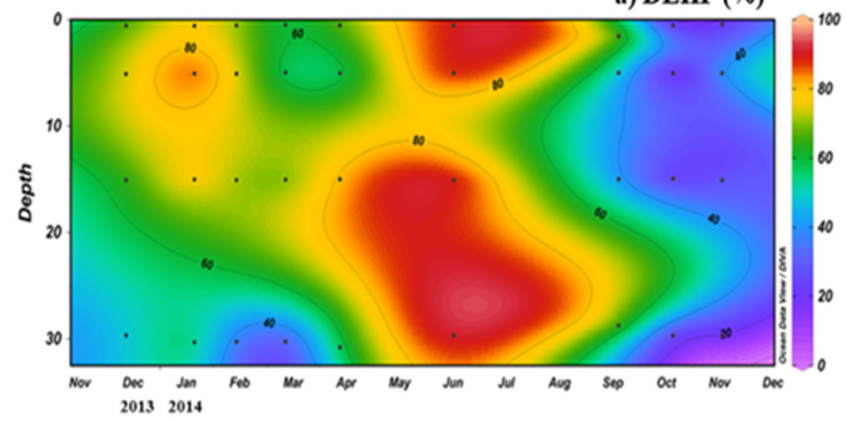

b) $\operatorname{DnBP}(\%)$

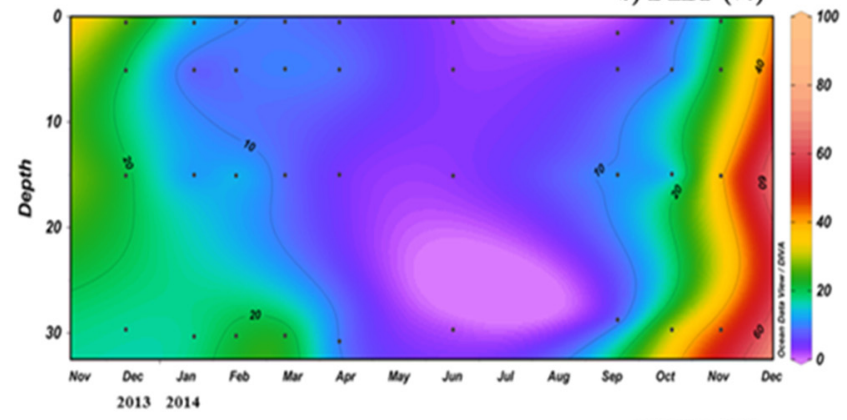

c) $\operatorname{DiBP}(\%)$

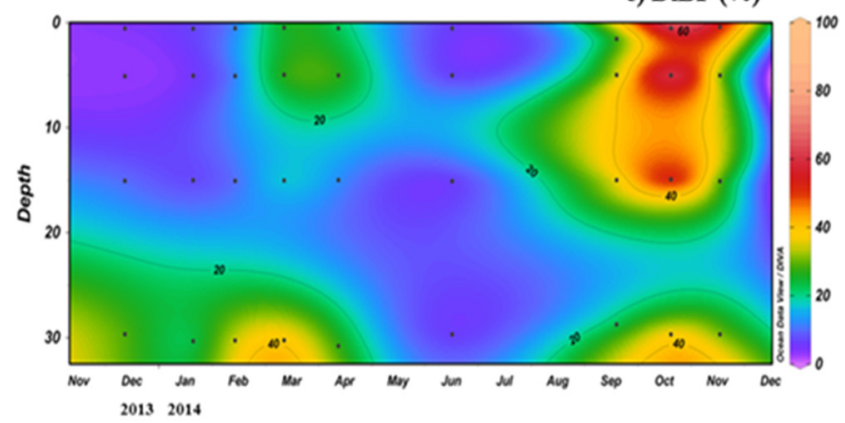

d) DEP (\%)

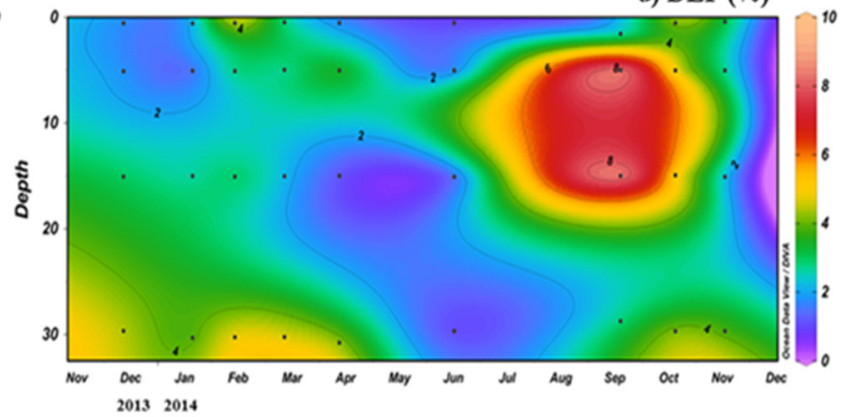

e) DMP (\%)

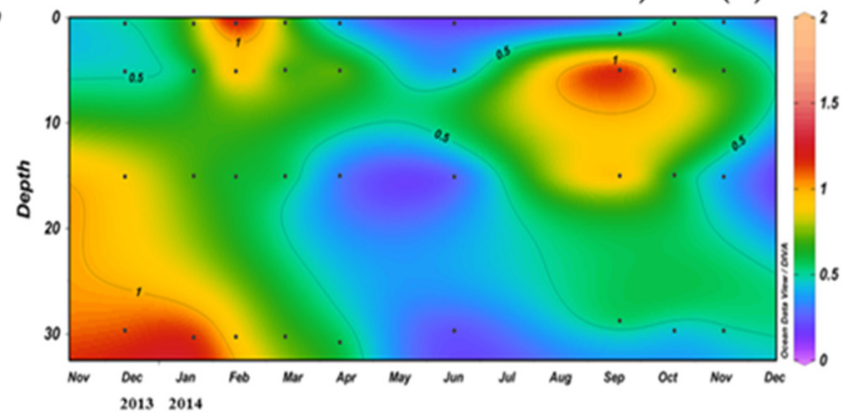

f) $\operatorname{BzBP}(\%)$

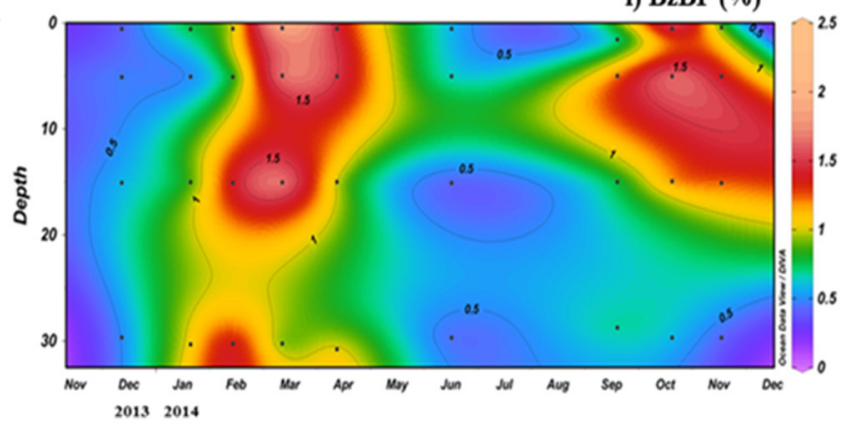

Fig. 4. Relative abundances for DEHP (a), DnBP (b), DiBP (c), DEP (d), DMP (e) and BzBP (f) at SUNMEX station in Marseille Bay from December 2013 to November 2014.

water column rather than above the bottom is very unlikely. Therefore, only photochemical degradation may explain such PAE concentration gradient along the vertical gradient.

This vertical gradient might also be connected to a concentration of plastic debris above the sea floor that may releases various chemical additives including phthalates into surrounding waters during their degradation as stated before. Indeed, accumulation of debris with a large proportion of plastic material has been observed several times, by trawling sampling and by video quantification based on recordings at the sea floor of the French Mediterranean coast including Marseille Bay (Galgani et al., 1995; Galgani et al., 1996; Galgani et al., 2000), the Rhone River plume area as well as canyons and continental slopes in the northwestern Mediterranean (Fabri et al., 2014). In most cases, plastic bags accounted for $>90 \%$ of the total debris (Galgani et al., 1995) and in particular in the eastern canyons of the Gulf of Lion (Galgani et al., 2000) close to Marseille. Such debris are likely PAE-producer candidates. Chemical diffusion from sediment, or sediment resuspension/ bioturbation could though explain higher PAE concentration close to the sediment. Resuspension episodes of PAE-rich sediment in the water column (originating from wind-driven turbulence and hydrodynamic features (Lapouyade, 2001) such as upwelling above the seafloor as previously reported for CDOM and DOC in Marseille Bay (Para et al., 2010)) are possible. However, higher DOC concentrations were not observed close to the sediment (Fig. 3e), supporting poor physical transport from the sediment toward the water column. Transport by chemical diffusion would therefore be predominant, in case PAEs input came from the sediment.

Interestingly, in Marseille Bay bottom samples, DiBP and DnBP relative abundance values were predominant over DEHP or higher (compared to surface waters) and match the period of high concentration of total PAEs. Indeed, in surface water samples, the relative abundance of DEHP, DnBP and DiBP averaged $66 \pm 18 \%, 11 \pm 6 \%$ and 21 $\pm 15 \%$, respectively, whereas these values averaged $48 \pm 21 \%, 21 \pm$ $12 \%$ and $32 \pm 14 \%$, respectively, in bottom samples during the year (Fig. 5). A possible explanation would be a higher degradation rate of LMW-PAEs close to the atmosphere/water interface due to higher organisms' density, as suggested by Yuan et al., 2010. The predominance (or higher relative abundance) of DnBP and DiBP versus DEHP in deepwater samples is in line with previous observations at a deep offshore station ( $z=2400 \mathrm{~m}$ ) (Paluselli et al., in press). The variation of PAE relative abundance near the bottom could also be explained considering the higher hydrophobicity of DEHP $\left(\log K_{\mathrm{ow}}=7.54\right.$, SPARC) compared with DnBP and DEP $\left(\log K_{\text {ow }}=4.63\right.$ and 2.51, respectively, SPARC), which could determine different grades of PAE repartition between sediment and water, making available a smaller dissolved fraction of DEHP and suggesting that DEP and even DnBP mainly exist under freely dissolved phase compared with DEHP. The higher desorption rate of these phthalate, with the exception of DEHP and DMP, in the interface sediment/water was already observed in a previous study (Mackintosh et al., 2006). 
Surface $(0,5 \mathrm{~m})$

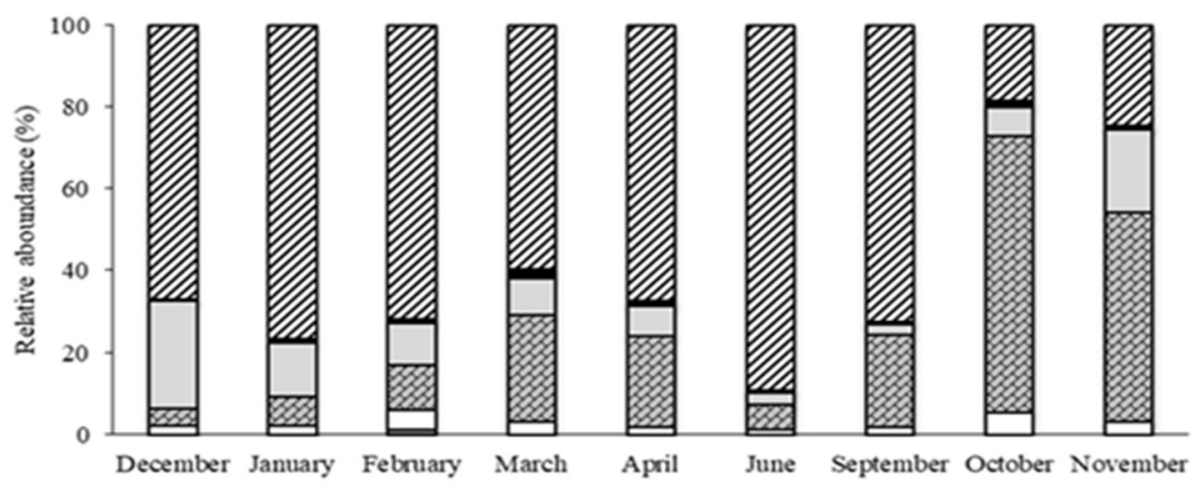

Bottom $(30 \mathrm{~m})$

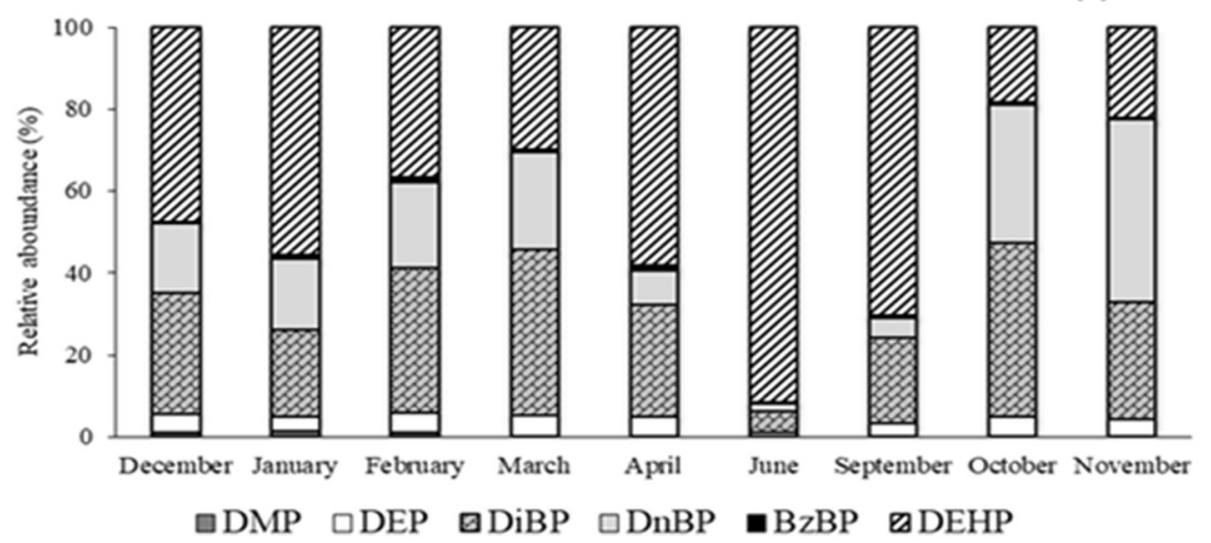

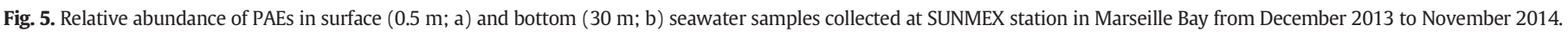

Surprisingly, a significant decrease of DEHP concentration and relative abundance was observed after the summer (October/November 2014) (Figs. 4-5). The change in relative abundance during fall, even on the surface, was due to an increase of DiBP and to a lesser extent DnBP and could be associated with potential resuspension as we observed only high PAE concentration in bottom samples. Note that
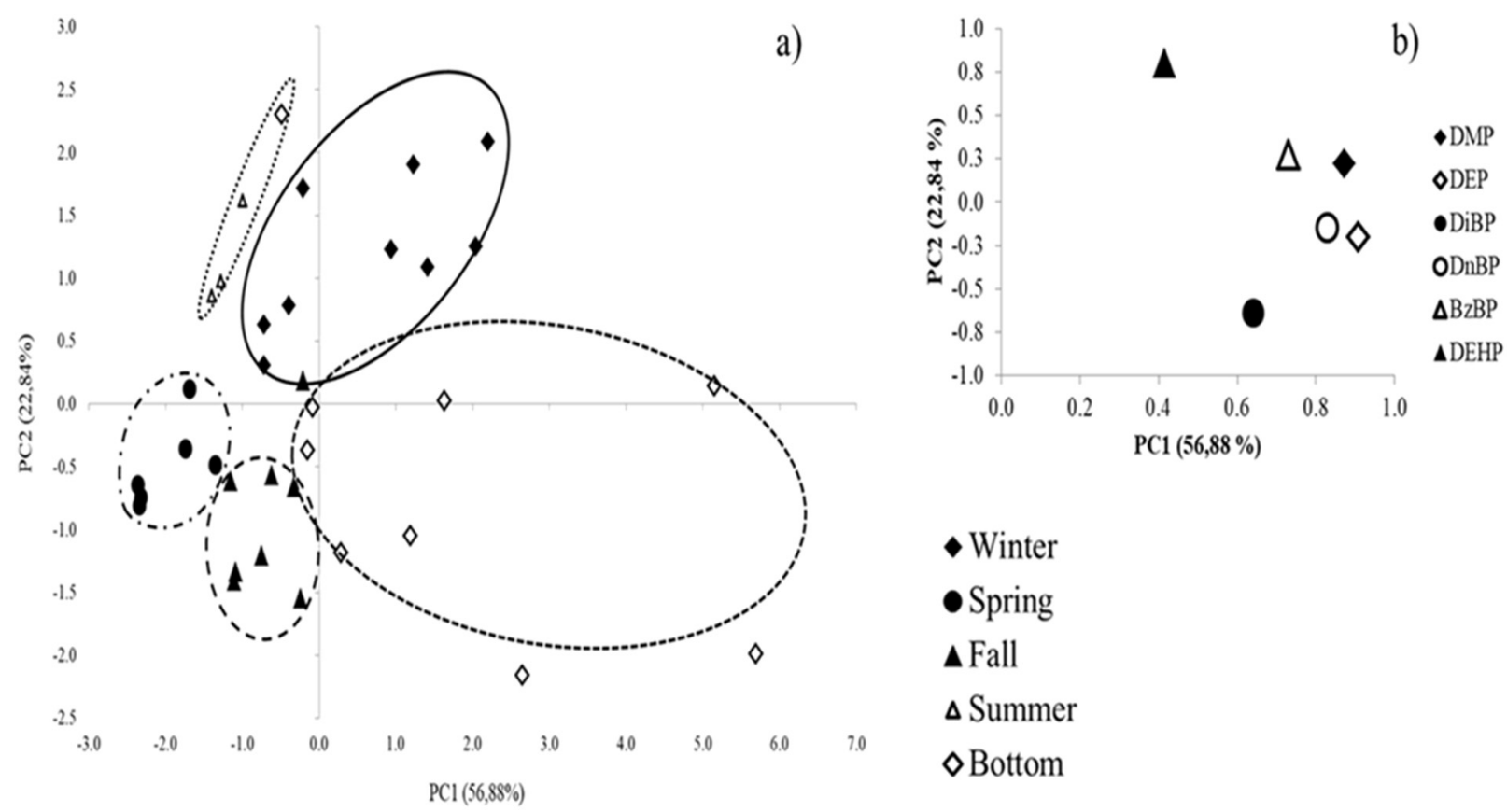

- Winter

- Spring

$\Delta$ Fall

$\Delta$ Summer

$\diamond$ Bottom

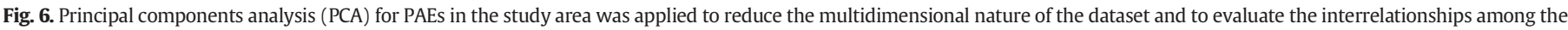

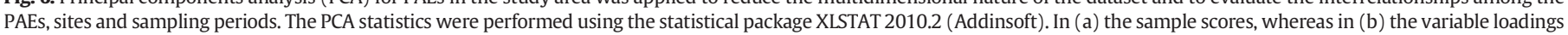
of the PCA. The variance accounted for by each principal component is shown in parentheses after the axis label. 


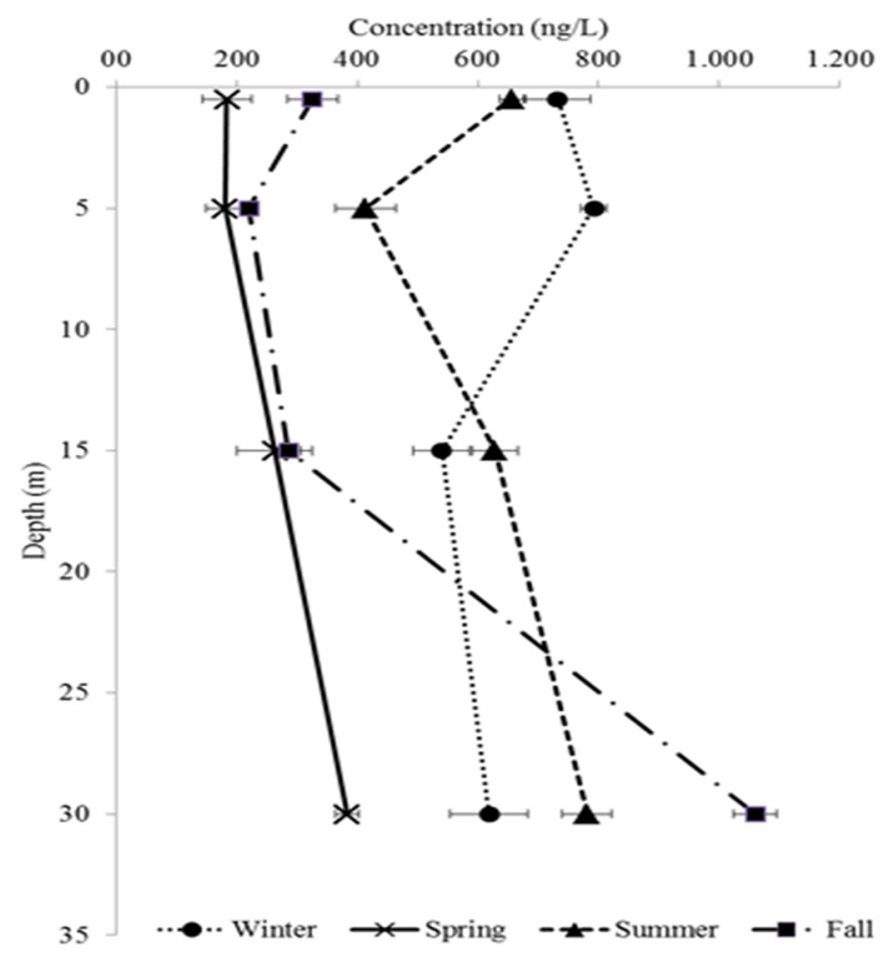

Fig. 7. $\sum$ PAEs vertical profile at Bay of Marseille in 4 seasons (average values) of 2014.

the variable intensity of the resuspension processes might be favored by the Northern Current entering into the Gulf of Lyon and being particularly high from October to May (Lapouyade, 2001) intensifying the inputs and shelf/slope exchange processes including turbulent mixing and vertical flux on the continental slope (Lapouyade, 2001; Monaco et al., 1999). In these circumstances exchange with the deep bottom, already observed to be rich in plastic debris, could represent a seasonal source of PAEs for the Bay of Marseille at the end of the stratification season, especially in the eastern canyons close to Marseille. This area was already noticed to accumulate most of the debris in the Gulf of Lyon, especially plastic bags (Galgani et al., 1995; Galgani et al., 1996). Our data together with others studies, suggest sediment resuspension as an important process explaining the heterogeneous vertical distribution. However, additional specific experiments are needed to confirm such hypothesis.

\section{Conclusion}

This study provides the first complete data on PAEs concentration levels in the Bay of Marseille (NW Mediterranean Sea). In addition, the first estimation of the PAEs annual occurrence and PAEs vertical distribution were reported here. The Marseille Bay, which is highly populated, displays levels of contamination of the same order of magnitude as other coastal area (NW Spanish coast, UK southern coast, Seine River; (Turner and Rawling, 2000; Brossa et al., 2005; Teil et al., 2007; Sanchez-Avila et al., 2012; Dargnat et al., 2009)). DEHP was detected as the predominant PAE congener in spring/summer season at Marseille area in the whole water column, whereas DiBP and DnBP were found to be abundant when close to the seafloor and especially in fall/winter season in the study areas. DMP, DEP and BzBP represent a minor fraction of PAEs pool and DnOP was never detected in the analyzed samples. The highest PAEs concentrations were detected close to the bottom and we have hypothesized a connection with the plastic debris accumulated over the seafloor and with PAEs in the sediment.

More research regarding PAEs input from plastic, and PAEs presence in the sediment should be implemented in the future to better identify the sources of the PAEs in the water column. Furthermore, more investigation is needed on the level of PAEs transfer to food web, for a better risk assessment and management policy.

\section{Acknowledgments}

This study was conducted as part of the project PLASTOX-JPI-Ocean, PlasticMicro-EC2CO and MERMEX/MISTRALS LAbex-OTMed projects and supported by 'Pole Mer Méditerranée'. This study is a contribution to the international SOLAS and LOICZ projects. We acknowledge the financial support from the PACA region, which provided a PhD scholarship for A. Paluselli. The authors are grateful to the crews of the R/V Antedon II and SAM-M I O platform for operation at sea as well as Patrick Raimbault, Nagib Bhairy for hydrological data and sampling and Anne Delmont for help in sampling and DOC analyses. Reviewers are kindly acknowledged for improving the revised version of the MS. The project leading to this publication has received funding from European FEDER Fund under project 1166-39417. A PhD scholarship for N. Schmidt was provided by Agence de l'Eau.

\section{References}

Ahrens, L., Gerwinski, W., Theobald, N., Ebinghaus, R., 2010. Sources of polyfluoroalkyl compounds in the North Sea, Baltic Sea and Norwegian Sea: evidence from their spatial distribution in surface water. Mar. Pollut. Bull. 60 (2), 255-260.

Andrady, A.L., 2011. Microplastics in the marine environment. Mar. Pollut. Bull. 62 (8), 1596-1605.

Barrier, N., Petrenko, A.A., Ourmières, Y., 2016. Strong intrusions of the Northern Mediterranean Current on the eastern Gulf of Lion: insights from in-situ observations and high resolution numerical modeling. Ocean Dyn. 66 (3), 313-327.

Bauer, M.J., Herrmann, R., Martin, A., Zellmann, H., 1998. Chemodynamics, transport behavior and treatment of phthalic acid esters in municipal landfill leachates. Water Sci. Technol. 38 (2), 185-192.

Berrojalbiz, N., Dachs, J., Ojeda, M.J., Valle, M.C., Castro-Jimenez, J., Wollgast, J., Ghiani, M. Hanke, G., Zaldivar, J.M., 2011. Biogeochemical and physical controls on concentrations of polycyclic aromatic hydrocarbons in water and plankton of the Mediterranean and Black Sea. Glob. Biogeochem. Cycles 25 (4).

Brossa, L., Marcé, R., Borrull, F., Pocurull, E., 2005. Occurrence of twenty-six endocrinedisrupting compounds in environmental water samples from Catalogna, Spain. Environ. Toxicol. Chem. 24, 261-267.

Buckley, J.P., Engel, S.M., Mendez, M.A., Richardson, D.B., Daniels, J.L., Calafat, A.M., Wolff, M.S., Herring, A.H., 2016. Prenatal phthalate exposures and childhood fat mass in a New York City cohort. Environ. Health Perspect. 124 (4), 507-513.

Castro-Jimenez, J., Deviller, G., Ghiani, M., Loos, R., Mariani, G., Skejo, H., Umlauf, G., Wollgast, J., Laugier, T., Heas-Moisan, K., Leaute, F., Munschy, C., Tixier, C., Tronczynski, J., 2008. PCDD/F and PCB multi-media ambient concentrations, congener patterns and occurrence in a Mediterranean coastal lagoon (Etang de Thau, France). Environ. Pollut. 156 (1), 123-125.

Castro-Jimenez, J., Eisenreich, S.J., Ghiani, M., Mariani, G., Skejo, H., Umlauf, G., Wollgast, J. Zaldivar, J.M., Berrojalbiz, N., Reuter, H.I., Dachs, J., 2010. Atmospheric occurrence and deposition of polychlorinated dibenzo-p-dioxins and dibenofurans (PCDD/Fs) in the open Mediterranean Sea. Environ. Sci. Technol. 44 (14), 5456-5463.

Collignon, A., Hecq, J.-H., Galgani, F., Voisin, P., Collard, F., Goffart, A., 2012. Neustonic microplastic and zooplankton in the North Western Mediterranean Sea. Mar. Pollut. Bull. 64, 861-864.

Commission Staff Working Document on the Implementation of the Community Strategy for Endocrine Disrupters-A Range of Substances Suspected of Interfering with the Hormone System of Humans and Wildlife. CEC (Commission of the European Communities), Brussels.

Cozar, A., Sanz-Martin, M., Marti, E., Gonzalez-Gordillo, J.I., Ubeda, B., Galvez, J.A., Irigoien, X., Duarte, C.M., 2015. Plastic accumulation in the Mediterranean Sea. PLoS ONE 10 (4).

Dafner, E., Sempéré, R., Bryden, H.L., 2001. Total organic carbon distribution and budget through the Strait of Gibraltar in April 1998. Mar. Chem. 73 (3-4), 233-252.

Dargnat, C., Teil, M.J., Chevreuil, M., Blanchard, M., 2009. Phthalate removal throughout wastewater treatment plant: case study of Marne Aval station (France). Sci. Total Environ. 407, 1235-1244.

Deudero, S., Alomar, C., 2015. Mediterranean marine biodiversity under threat: reviewing influence of marine litter on species. Mar. Pollut. Bull. 98 (1-2), 58-68.

Doval, M.D., Perez, F.F., Berdalet, E., 1999. Dissolved and particulate organic carbon and nitrogen in the Northwestern Mediterranean. Deep-Sea Res. Part I Oceanogr. Res. Pap. 46 (3), 511-537.

Fabri, M.-C., Pedel, L., Beuck, L., Galgani, F., Hebbeln, D., Freiwald, A., 2014. Megafauna of vulnerable marine ecosystems in French mediterranean submarine canyons: Spatial distribution and anthropogenic impacts. Deep Sea Res. Part 2 Top. Stud. Oceanogr. 104, 184-207.

Faure, F., Demars, C., Wieser, O., Kunz, M., De Alencastro, L.F., 2015. Plastic pollution in Swiss surface waters: nature and concentrations, interaction with pollutants. Environ. Chem. 12 (5), 582-591.

Ferreira, I.D., Morita, D.M., 2012. Ex-situ bioremediation of Brazilian soil contaminated with plasticizers process wastes. Braz. J. Chem. Eng. 29 (1), 77-86. 
Fraysse, M., Pairaud, I., Ross, O.N., Faure, V.M., Pinazo, C., 2014. Intrusion of Rhone River diluted water into the Bay of Marseille: generation processes and impacts on ecosystem functioning. J. Geophys. Res. 119 (10), 6535-6556.

Fromme, H., Kuchler, T., Otto, T., Pilz, K., Muller, L., Wenzel, A., 2002. Occurrence of phthalates and bisphenol $\mathrm{A}$ and $\mathrm{F}$ in the environment. Water Res. 36, 1429-1438.

Fu, P., Kawamura, K., Barrie, L.A., 2009. Photochemical and other source of organic compounds in the Canadian high Artic aerosol pollution during winter-spring. Environ. Sci. Technol. 43, 286-292.

Fu, P., Kawamura, K., Chen, J., Charrière, B., Sempéré, R., 2013. Organic molecular composition of marine aerosols over the Arctic Ocean in summer: contributions of primary emission and secondary aerosol formation. Biogeosciences 10, 653-667.

Galgani, F., Jaunet, S., Campillo, A., Guenegen, X., His, E., 1995. Distribution and abundance of debris on the continental shelf of the north-western Mediterranean Sea. Mar. Pollut. Bull. 30 (11), 713-717.

Galgani, F., Souplet, A., Cadiou, Y., 1996. Accumulation of debris on the deep sea floor off the French Mediterranean coast. Mar. Ecol. Prog. Ser. 142 (1-3), 225-234.

Galgani, F., Leaute, J.P., Moguedet, P., Souplet, A., Verin, Y., Carpentier, A., Goraguer, H. Latrouite, D., Andral, B., Cadiou, Y., Mahe, J.C., Poulard, J.C., Nerisson, P., 2000. Litter on the sea floor along European coasts. Mar. Pollut. Bull. 40 (6), 516-527.

Gatti, J., Petrenko, A., Devenon, J.L., Leredde, Y., Ulses, C., 2006. The Rhone River dilution zone present in the northeastern shelf of the Gulf of Lion in December 2003. Cont. Shelf Res. 26 (15), 1794-1805.

Gu, J., Han, B., Duan, S., Zhao, Z., Wang, Y., 2009. Degradation of the endocrine-disrupting dimethyl phthalate carboxylic ester by Sphingomonas yanoikuyae DOS01 isolated from the South China Sea and the biochemical pathway. Int. Biodeterior. Biodegrad. 63 (4), 450-455.

Halden, R.U., 2010. Plastics and health risks. Annu. Rev. Public Health 31, 179-194.

He, W., Qin, N., Kong, X., Liu, W., He, Q., Ouyang, H., Yang, C., Jiang, Y., Wang, Q., Yang, B., $\mathrm{Xu}, \mathrm{F} ., 2013$. Spatio-temporal distributions and the ecological and health risks of phthalate esters (PAEs) in the surface water of a large, shallow Chinese lake. Sci. Total Environ. 461-462, 672-680.

Holahan, M.R., Smith, C.A., 2015. Phthalates and neurotoxic effects on hippocampal network plasticity. Neuro Toxicology 48, 21-34.

Horn, O., Nalli, S., Cooper, D., Nicell, J., 2004. Plasticizer metabolites in the environment. Water Res. 38, 3693-3698.

Howdeshell, K.I., Rider, C.V., Wilson, V.S., Gray Jr., L.E., 2008. Mechanisms of action of phthalate esters, individually and in combination, to induce abnormal reproductive development in male laboratory rats. Environ. Res. 108 (2), 168-176.

IARC, 2000. Some industrial chemicals, di(2-ethylhexyl) phthalate. IARC Monogr. Eval. Carcinog. Risks Hum. 77, 41-148.

Iwaki, H., Nishimura, A., Hasegawa, Y., 2012. Isolation and characterization of marine bac teria capable of utilizing phthalate. World J. Microbiol. Biotechnol. 28 (3), 1321-1325.

Kimber, I., Dearman, R.J., 2010. An assessment of the ability of phthalates to influence immune and allergic responses. Toxicology 271 (3), 73-82.

Kolena, B., Petrovivova, I., Pilka, T., Pucherova, Z., Munk, M., Matula, B., Vankova, V., Petlus, P., Jenisova, Z., Rozova, Z., Wimmerova, S., Trnovec, T., 2014. Phthalate exposure and health-related outcomes in specific types of work environment. Int. J. Environ. Res. Public Health 11 (6), 5628-5639.

Lammel, G., Audy, O., Besis, A., Efstathiou, C., Eleftheriasis, K., Kohoutek, J., Kukucka, P. Mulder, M.D., Pribylova, P., Prokes, R., Rusina, T.P., Samara, C., Sofuoglu, A., Sofuoglu, S., Tasdemir, Y., Vassilatou, V., Voutsa, D., Vrana, B., 2015. Air and seawater pollution and air-sea gas exchange of persistent toxic substances in the Aegean Sea: spatial trendes of PAHs, PCBs, OCPs and PBDEs. Environ. Sci. Pollut. Res. 22 (15), $11301-11313$

Lapouyade, A., 2001. Durrieu de Madron, X. Seasonal variability of the advective transport of particulate matter and organic carbon in the Gulf of Lion (NW Mediterranean) Oceanol. Acta 24 (3), 295-312.

Mackintosh, C., Maldonado, J., Ikonomou, M.A., Gobas, P.C., 2006. Sorption of phthalate esters and PCBs in a marine ecosystem. Environ. Sci. Technol. 40, 3481-3488.

Monaco, A., Durrieu de Madron, X., Radakovitch, O., Heussner, J., Carbonne, J., 1999. Origin and variability of downward biogeochemical fluxes on the Rhone continental margin (NW Mediterranean). Deep-Sea Res. Part I Oceanogr. Res. Pap. 46 (9), 1483-1511.

National Standard of the People's Republic of China, 2006. Standard for Drinking Water Quality. GB. p. 5749.

Net, S., Delmont, A., Sempéré, R., Paluselli, A., Ouddane, B., 2015a. Reliable quantification of phthalates in environmental matrices (air, water, sludge, sediment and soil): a review. Sci. Total Environ. 515-516:162-180. https://doi.org/10.1016/j.scitotenv.2015.02.013.

Net, S., Sempéré, R., Delmont, A., Paluselli, A., Ouddane, B., 2015b. Occurrence, fate, behavior and ecotoxicological state of phthalates in different environmental matrices. Environ. Sci. Technol. 49 (7), 4019-4035.

Okamoto, Y., Ueda, K., Kojima, N., 2011. Potential risks of phthalates esters: acquisition of endocrine-disrupting activity during environmental and metabolic processing. J. Health Sci. 57, 497-503.

Paluselli, A., Aminot, Y., Galgani, F., Net, S., Sempéré, R., 2017. Occurrence of phthalate acid esters (PAEs) in the northwestern Mediterranean Sea and the Rhone River. Prog. Oceanogr. (in press). https://doi.org/10.1016/j.pocean.2017.06.002.

Panagiotopoulos, C., Sempéré, R., Para, J., Raimbault, P., Rabouille, C., Charrière, B., 2012. The composition and flux of particulate and dissolved carbohydrates from the Rhone River into the Mediterranean Sea. Biogeosciences 9, 1827-1844.

Para, J., Coble, P.G., Charrière, B., Tedetti, M., Fontana, C., Sempéré, R., 2010. Fluorescence and absorption properties of chromophoric dissolved organic matter (CDOM) in coastal surface waters of the northwestern Mediterranean Sea, influence of the Rhône Rive not completer. Biogeosciences 7, 4083-4103.

Pedrotti, M.L., Petit, S., Elineau, A., Bruzaud, S., Crebassa, J.C., Dumontet, B., Marti, E., Gorsky, G., Cozar, A., 2016. Changes in the floating plastic pollution of the Mediterranean Sea in relation to the distance to land. PLoS ONE 11 (8).

Rahman, M., Brazel, C.S., 2004. The plasticizer market: an assessment of traditional plasticizers and research trends to meet new challenges. Prog. Polym. Sci. 29, 1223-1248.

Ruiz-Orejon, L.F., Sarda, R., Ramis-Pujol, J., 2016. Floating plastic debris in the Central and Western Mediterranean Sea. Mar. Environ. Res. 120, 136-144.

Sanchez-Avila, J., Tauler, R., Lacorte, S., 2012. Organic micropollutants in coastal waters from NW Mediterranean Sea: Sources distribution and potential risk. Environ. Int. $46,50-62$.

Santinelli, C., Sempéré, R., Van-Wambeke, F., Charriere, B., Seritti, A., 2012. Organic carbon dynamics in the Mediterranean Sea: an integrated study. Glob. Biogeochem. Cycles 26.

Schmidt, N. Thibault, D., Galgani, F., Paluselli, A., Sempéré, R., 2017. Occurrence of microplastics and potential contribution of phthalates in the surface waters of the Gulf of Lion (NW Mediterranean Sea). Prog. Oceanogr. https://doi.org/10.1016/ j.pocean.2017.11.010 (in press).

Sempéré, R., Charrière, B., Van Wambeke, F., Cauwet, G., 2000. Carbon inputs of the Rhône river to the Mediterranean Sea: biogeochemical implications. Glob. Biogeochem. Cycles 14 (2), 669-681.

Sempéré, R., Panagiotopoulos, C., Lafont, R., Marroni, B., Van Wambeke, F., 2002. Total organic dynamics in the Aegean Sea. J. Mar. Syst. 33-34, 355-364.

Sempéré, R., Dafner, E., Van Wambeke, F., Lefevre, D., Magen, C., Allegre, S., Bruyant, F., Bianchi, M., Prieur, L., 2003. Distribution and cycling of total organic carbon across the Almeria-Oran Front in the Mediterranean Sea: implications for carbon cycling in the western basin. J. Geophys. Res. 108.

Sempéré, R., Tedetti, M., Panagiotopoulos, C., Charrière, B., Van Wambeke, F., 2008. Distribution and bacterial availability of dissolved neutral sugars in the South East Pacific. Biogeosciences 5, 1165-1173.

Sempéré, R., Para, J., Tedetti, M., Chattière, B., Mallet, M., 2015. Variability of Solar radiation and CDOM in Surface Coastal Waters of the Northwestern Mediterranean Sea. Photochem. Photobiol. 91 (4) (851-561).

Sempéré, R., Charrière, B., Castro-Jimenez, J., Kawamura, K., Panagiotopoulos, C., 2017. Occurrence of $\alpha, \omega$-dicarboxylic acids and $\omega$-oxoacids in the surface waters of the Rhone River and fluxes into the Mediterranea Sea. Prog. Oceanogr. (in press). https://doi.org/10.1016/j.pocean.2017.07.002.

Serôdio, P., Nogueria, J.M.F., 2006. Considerations on ultra-trace analysis of phthalates in drinking water. Water Res. 40 (13), 2572-2582.

Sicre, M.A., Fernandes, M.B., Pont, D., 2008. Poly-aromatic hydrocarbon (PAH) inputs from the Rhone River to the Mediterranean Sea in relation with the hydrological cycle: impact of floods. Mar. Pollut. Bull. 56 (11), 1935-1942.

Staples, C.A., Peterson, D.R., Parkerton, T.F., Adams, W.J., 1997. The environmental fate of phthalate esters: a literature review. Chemosphere 35 (4), 667-749.

Suaria, G., Avio, C.G., Mineo, A., Lattin, G.L., Magaldi, M.G., Belmonte, G., Moore, C.J., Regoli, F., Aliani, S., 2016. The Mediterranean plastic soup: synthetic polymers in Mediterranean surface waters. Nat. Sci. Rep. 6, 37551.

Tedetti, M., Kawamura, K., Charriere, B., Chevalier, N., Sempéré, R., 2006. Determination of low molecular weight dicarboxylic and ketocarboxylic acids in seawater samples. Anal. Chem. 78, 6012-6018.

Teil, M., Blanchard, M., Dargnat, C., Larcher-Tiphagne, K., Chevreuil, M., 2007. Occurrence of phthalates diesters in river of the Paris district (France). Hydrol. Process. 21, $2515-2525$

The Mermex Group, 2011. Marine ecosystems responses to climatic and anthropogenic forcings in the Mediterranean. Prog. Oceanogr. 91, 97-166.

Turner, A., Rawling, M.C., 2000. The behaviour of di-(2-ethylhexyl) phthalate in estuaries. Mar. Chem. 68 (3), 203-217.

UNEP Chemicals, 2002. Regionally based assessment of persistent toxic substances. Mediterranean Regional Report. UNEP, Geneve.

United States Environmental Protection Agency, December 2014. 40 CFR Part 423, Appendix A. https://www.epa.gov/sites/production/files/2015-09/documents/priority-pollutant-list-epa.pdf.

Wang, Y., Zeng, Q., Sun, Y., You, L., Wang, P., Li, M., Yang, P., Li, J., Huang, Z., Wang, C., Li, S., Dan, Y. Li, Y., 2016. Phthalate exposure in association with serum hormone levels, sperm DNA damage and spermatozoa apoptosis: a cross-sectional study in China. Environ. Res. 150, 557-565.

Xie, Z., Ebinghaus, R., Temme, C., Caba, A., Ruck, W., 2005. Atmospheric concentrations and air-sea exchanges of phthalates in the North Sea (German Bight). Atmos. Environ. 39, 3209-3219.

Xie, Z., Selzer, J., Ebinghaus, R., Caba, A., Ruck, W., 2006. Development and validation of a method for the determination of trace alkylphenols and phthalates in the atmosphere. Anal. Chim. Acta 565, 198-207.

Xie, Z., Ebinghaus, R., Temme, C., Lohmann, R., Caba, A., Ruck, W., 2007. Occurrence and air-sea exchange of phthalates in the Arctic. Environ. Sci. Technol. 41, 4555-4560.

Yuan, S., Huang, I., Chang, B., 2010. Biodegradation of dibutyl phthalate and di-(2ethylhexyl) phthalate and microbial community changes in mangrove sediment. J. Hazard. Mater. 184 (1-3), 826-831.

Zeng, F., Cui, K., Xie, Z., Liu, M., Li, Y., Lin, Y., Zeng, Z., Li, F., 2008. Occurrence of phthalate esters in water and sediment of urban lakes in a subtropical city, Guangzhou, South China. Environ. Int. 34, 372-380. 